\title{
A TRANSZFERÁRRENDSZER ÉS A VÁLLALATI SZERVEZETI RENDSZER ÖSSZEFÜGGÉSEI
}

A transzferárak alkalmazása a nemzetközi szakmai publikációkban már több évtizedes múltra tekint viszsza, ráadásul nem alapvetóen az adóoptimalizáló jellege miatt. A vállalati szervezeti rendszerek fejlódésével, a vállalatvezetés területén a stratégiai gondolkodás jelentóségének növekedésével, valamint a globalizációs folyamatok kialakulásával és felerôsödésével egyre komolyabb figyelmet kapott. A transzferárazás a vállalatvezetés eszközrendszerének eleme, a stratégiai vezetối számvitel egyik területe. Ezen a bázison a szerzố célja a lehetséges transzferárrendszerek vizsgálata a vállalati szervezeti rendszer sajátosságainak függvényében, valamint a belsố árak képzésére ható tényezốk vizsgálata a vonatkozó nemzetközi szakirodalom áttekintése alapján.

\section{Kulcsszavak: transzferár, belsố elszámoló árak, decentralizált szervezet, köztes termék}

Az elmúlt húsz-harminc évben a globalizációs folyamatok erősödése, a nemzetközi kereskedelmi kapcsolatok alakulása a gazdasági konzultációk középpontjában tartották a multinacionális vállalatok belsố árképzésének problémáját. A kategória értelmezése meglehetôsen egyszerú, hiszen a vállalati részlegek, divíziók, illetve leányvállalatok közötti kereskedelmi és pénzügyi tranzakciókban alkalmazott árról van szó. Ezzel az egyszerú fogalmi meghatározással azonban a vállalati vezetés és tervezés, a vállalati folyamatszervezés, teljesítménymérés és értékelés, és nem utolsósorban a vállalati nyereség vállalaton belüli, illetve az adófizetés révén a vállalat és az állam közötti elosztása terén komoly kérdések merülnek fel.

A transzferár-kategória összetett szerepe a vállalatcsoport múködésében jól tükröződik abban, hogy különböző tudományterületek szakemberei - elméleti közgazdászok, a gazdasági folyamatok matematikai modellezői, a vállalati menedzsment tudományterületek kutatói, számviteli szakemberek - egyaránt foglalkoztak a vizsgálatával.

Az árképzés nem tekinthetô egzakt tudománynak, hiszen az árazásban a vállalkozások a piaci, gazdasági és stratégiai jellemzóik függvényében a lehető legjobb eredmény elérésére törekednek, általános képlet azonban csak meglehetôsen nagyvonalú formában írható fel az árkalkulációra. Igaz ez a belsô ügyletekben kialakított elszámoló árakra is, hiszen valamennyi kutatási eredmény csupán feltételrendszert, árazási keretrendszert volt képes felállítani. Az árak kialakítása a vállalaton belüli folyamatokban a piaci információk mellett a vállalati jövedelem belsố elosztásának, a vezetôi motivációs és értékelő rendszer kialakításának, a részlegek és az összvállalati érdek összehangolásának figyelembevételét is igényli. Ezáltal az elszámoló árak meghatározása még inkább összetett feladatnak számít a menedzsment számára.

\section{A transzferárazás és a vállalati szervezeti rendszer kapcsolata}

A transzferár-kategória szorosan kapcsolódik a vállalati szervezeti rendszerek fejlődéséhez. Szerepe egy szervezeti rendszer múködéséből következik, ugyanakkor annak jelenére és jövőjére is alapvető hatással van. Az alkalmazása során a vállalatvezetés különböző területei és különböző vezetôii szintjei érintettek, ezért a bevezetésének és múködésének alapvetô keretet maga a szervezeti rendszer szab, hatékonyságát pedig a szervezeten belüli kommunikáció jelentősen befolyásolja. 
A szervezeti rendszerek változása a külsố gazdasági környezet kihívásainak függvényében alakul. A gazdasági környezet stabilitása mellett a vállalkozások belsố szervezetét múködési szabályzatok és a hatalom egyértelmú hierarchiája határozza meg. Az ilyen formalizált, központosított döntéshozásra épülő szervezeti formát Burns és Stalker „mechanikus” szervezeti rendszernek (Kaplan - Atkinson, 1998: 284. old.), míg a szervezeti struktúrákkal foglalkozó szakirodalmak jellemzően centralizált rendszerként definiálják. E rendszerek múködésében a vállalatok mérete, a feladatok specializációja, a tulajdonosi és vezetôi öszszefonódás és a tevékenység bonyolultsága alapján a hierarchikus, többnyire egyszemélyi vezetés jellemző.

A gyorsan változó gazdasági környezet azonban a vállalatok tevékenységének bonyolultabbá válásával, a belső folyamatok jellegének megváltozásával, a folyamatokon belüli és azok közötti együttmúködés igényének felerősödésével, valamint a környezeti információk számának növekedésével és a válaszreakciók idejének csökkenési igényével a szervezeti rendszer decentralizációjához vezet. Ezen okok között nehéz sorrendet felállítani, de talán a döntési pozíciókhoz tartozó tapasztalat és szakértelem, a reakcióidő́k csökkenése az információáramlás útjának lerövidítésével, illetve a vezetôi szintek közötti munkamegosztás gyakorlati alkalmazása jelenti a legnagyobb előnyt, és egyúttal kihívást is.

A decentralizált vállalati múködés legegyszerúbb formája a funkcionális szervezet, amelynek kialakítása alapvetóen az input oldalhoz kötődik, a szervezetben a struktúra az inputok szerinti tagozódást követi. A szokásos vállalati funkciók: pénzügy, anyaggazdálkodás, termelésirányítás, marketing, kutatás és fejlesztés stb. $\mathrm{Az}$ egyes funkciók vezetőinek ismérvei alapvetôen a szervezeti sajátosságok alapján határozhatók meg. A funkció vezetôje a vállalati tevékenység egészéból egy jól körülhatárolható területet kap, amelyet szakmai ismeretei alapján képes jól ellátni. A szaktudás alapvető követelmény az adott terület legjobb hatásfokú múködtetése érdekében. Tevékenységét csak kismértékben befolyásolják más funkciók, a felelóssége jól behatárolt, viszonylagos önállósággal rendelkezik. A vállalati stratégia szempontjából a funkcionális vezetô inkább végrehajtó, mint alkotó. A vezetői teljesítményének értékelése a rövidebb távú operatív tervekhez, költségvetéshez kötődik, kockázatvállalása is korlátozott (Barakonyi, 2002).

A decentralizáció révén kialakult szervezeti forma a divizionális szervezet, amelynek strukturális kialakítása az outputok, azaz a termékek, tevékenységek szerint valósul meg. Ennek eredményeképpen a környezeti hatásokra való reakcióidő jelentôsen csökkent. Így a divizionális szervezet vezetőjének felelőssége szélesebb körú, mint a már említett funkcionális szervezeti vezetô felelőssége. A divizionális szervezet nemcsak a végrehajtó típusú menedzsmentet igényli, hanem a környezettel szoros kapcsolatban lévô, annak változásait nemcsak utólag követô, de kezdeményező típusú, a döntéshozás terén megelőzó jelleggel, előre gondolkodó stratégiai vezetést is. Solomons (Solomons, 1983) úgy fogalmaz, hogy divizionális szervezetre jellemző a decentralizáción túl a vállalati nyereségesség felelôsségének delegálása a divíziómenedzsment szintjére. A divízió vezetôje felelős a szervezeti egység profitabilitásáért, tervezési, termelési, értékesítési, pénzügyi és számviteli tevékenységéért. Solomons négy pontban rendszerezi a divizionális szervezeti rendszer elônyeit (Solomons, 1983):

1. A diverzifikáció lehetőséget ad a különféle tevékenységek megfelelő szervezeti egységben való múködésére, ugyanakkor könnyedén kezelhetô a rendszer egyetlen egységként.

2. A döntéshozás légkörének kialakítása a divíziók szintjén - lehetôséget teremteni a kreatív képességeknek az egyéni felelősség és hatalom gyakorlására.

3. A divízióvezetốk célja a hosszú távú jövedelmezőség biztosítása a vállalat egésze számára, ezért a vállalati nyereséghez való hozzájárulás mérése a rendszer velejárója. A vállalat vezetése megfelelő szintú önállóságot biztosít a divízióknak gazdasági döntéshozásukban, ami a teljesítménymérés lehetőségének feltétele.

4. A divíziók menedzsmentpozíciói első osztályú tréninget jelentenek a vállalat jövőbeni topmenedzsmentje számára. A divíziók szintjén az üzleti élet valamennyi problémája, különféle döntési szituációk megfelelő tapasztalatszerzésként értékelhetô.

A divizionális szervezeti rendszer elméletileg előnyös vállalati struktúra, de a sikeres múködésnek van néhány alapvetố feltétele. A részlegek független múködési feltételeinek biztosítása elengedhetetlen a nyereségesség méréséhez. Mivel jellemzóen a tevékenység, termék alapján történik a divíziók kialakítása, így természetesen a vállalatvezetésnek megfelelő rálátással kell bírnia valamennyi üzleti területre, amelyekben a részlegek tevékenységüket kifejtik. Ez egyrészt a megfelelő kontroll alapfeltétele, másrészt a részlegek közötti együttmúködés lehetôségeinek felismerése révén összvállalati érdek. Az együttmúködés kritikus kérdése a profitorientáltság, illetve a divíziók profitcéljainak és a vállalati profitcéloknak az együttes érvényesülése. 
A részlegek közötti verseny a rendszer velejárója, ugyanakkor a verseny kézbentartása, különösen, ha az egyik részleg profitja a másik veszteségét jelenti, ugyancsak hosszú távú gondolkodást igényel. A vállalatvezetés részéról kihívás, de egyúttal alapvetô feltétel is, hogy megfelelő önkontrollt gyakoroljon a vállalati iránymutatások, direktívák kialakításával, a divíziók függetlenségének megtartása érdekében.

$\mathrm{Az}$ áttekintett szervezeti rendszerek a gyakorlatban ritkán múködnek tiszta formában. A cégek igyekeznek valamennyi szervezeti modell előnyeit kihasználni, úgymond hibrid rendszereket kialakítani, amelyek a környezeti kihívásokra a lehetô legjobb válaszadási lehetőségeket adják.

\section{A transzferárazás számviteli közelítése}

A transzferár-kategória számviteli vonatkozása az ár szerkezetére épül. Maga az ár a termék előállításának költsége és a termék értékesítésén elérni kívánt haszon összegeként értelmezhető. A költség- és haszonkategória egyszerúnek túnik azon gazdasági tevékenység vizsgálatáig, amely alapján ármeghatározásra törekszünk. Ekkor ugyanis elő́kerül az előállítási költség tartalmának kérdése, a direkt és allokációs módszerekkel a termékhez rendelhetô erooforrás-felhasználások problémája, a haszonkategória alatt pedig a tevékenység teljes költség-alakulásának vizsgálata, a fedezeti ponthoz tartozó kibocsátási szint meghatározása, illetve ebból adódóan a termék árának nyereségtartalma mint megválaszolandó alapvető kérdéskör. Mindezek a területek a vállalkozás piaci feltételrendszerének függvényében a vezetés részérốl a piac alapvetố ismeretét igénylik a termékstruktúrában, a piaci szereplókben, az ügyfelekben, az elérhetô erőforrásokban egyaránt. A realizációs folyamatok és a nyereségesség érdekében a külső információk hangsúlyosak a menedzsment számára. A transzferár problémája pedig az árnak éppen a realizációs folyamatokban megjelenő szerepén és hatásán nyugszik.

A vezetői számviteli kutatások szerint a transzferár a vállalaton belüli erőforrás-allokációban alapvetố szerepet tölt be, ezáltal befolyásolva a szervezeti egységek rendszeren belüli pozícióját, a részrendszerek és a vállalat egészének tevékenységével összefüggő alapvető döntési szituációkat (például make-or-buy, tervezési és befektetési, termékmegszüntetési, végtermék-árazási döntések), valamint a teljesítménymérés és -értékelés kialakítását és múködését. Rosszul választott transzferár tehát nemcsak a vállalkozás eredményének nagyságára és struktúrájára lesz hatással, hanem a döntési szintek motivációjának veszélyeztetésével a hosszú távú múködést kérdőjelezheti meg.
A közgazdasági elméleti kutatások terén Hirshleifer ${ }^{1}$ transzferárelmélete szolgál alapul a késóbbi transzferárazással kapcsolatos kutatásokhoz. Hirshleifer a köztes termékek piaci körülményeinek, a végtermék piacának és a vállalati részlegek integrált tevékenysége alapján a határköltség-alapú árazást, illetve a transzferár optimális kibocsátást szabályozó funkcióját tartja igazolhatónak. A számviteli kutatók közül Solomons volt az elsô, aki Hirshleifer eredményeinek gyakorlati alkalmazhatóságát vizsgálta. Szerinte az ármeghatározás a belsô ügyletekben alapvetően attól függ, hogy

- van-e kompetitív piaca a belsố ügyletben szereplő terméknek, ahol a divíziók szabadon megjelenhetnek?

- ha nincs a köztes terméknek kompetitív piaca akkor a belsố ügyletben szereplô termék lényeges volument vagy értéket képvisel-e?

- ha nincs a köztes terméknek kompetitív piaca és a belső forgalom jelentôs, akkor a szállító divízió kapacitása elegendő-e a kereslet teljes kielégítésére?

E feltételrendszer elemeinek lehetséges kombinációi alapján Solomons öt eshetôséget vizsgált meg. Természetesen nem mindegyiknek van realitása, így az ármeghatározásnál sem adódik egyértelmú válasz (Solomons, 1983).

a) A köztes terméknek van kompetitív külsó piaca, ahová a divíziók szabadon beléphetnek. Ez esetben a divíziók önállósága egyértelmúen létezik, döntéseiket a divízió jövedelmezôsége érdekében hozzák meg. Mivel a piaci információk rendelkezésre állnak, és a piaci tevékenységük a vállalati vezetés által nem korlátozott, így a belsô ügyletekben egyértelmúen csak a piaci árnak van jogosultsága.

b) Nincs külsố piac a köztes termékre, és a belsó kereskedelme sem jelentốs. Ez a feltétel azt jelenti, hogy nincs különösebb belső feszültség az ügyletben részt vevố részlegek között, mivel az eredményük alakulására nincs meghatározó befolyása a transzferáraknak. Ebben a helyzetben Solomons szerint nem kell komplex transzferárrendszerrel számolnia a vállalkozásnak, meghagyhatja az ár kialakítását a divízióknak. Tipikusan a költségek és elfogadható, ésszerú, a befektetés megtérülését biztosító hasznot tartalmazó ár alkalmazása segíti a legjobban a folyamatok múködését. Ennek megfelelően a tốkearányos haszon (ROC) ajánlott az árkalkulációban.

c) A belsố ügyletben jelentốs, vagy potenciálisan jelentôs termékvolumen, olyan termék esetén, amellyel a külsó kompetitív piacon más szállitó 
nem kereskedik, illetve a belsố szállitó üzleti tevékenységében sem képvisel jelentôs részt. Ebben a helyzetben a transzferárak kialakítása már komplexebb gondolkodást igényel, mivel a belsố ügyletben nagy volumenek kerülnek értékesítésre. Az előző szituációhoz képest a haszon meghatározása érezhetôbb hatással bír a részlegek nyereségére, a belsô összhang érdekében a teljes folyamaton realizált haszon egyenletes elosztása tipikus, azaz a tôkearányos jövedelmezôség mértéke jellemzően egyforma kell, hogy legyen a divízióknál. Solomons kétlépéses eljárást javasol a belső szállítónak a belső árazásra: egyrészt termékenkénti díjat a termelő határköltségének és a disztribútorrészleg határbevételének metszéspontjában lévô volumen alapján. Ez a díj fedezi a változó költségeket és a fix költségek egy részét is. Másrészt éves fix összeg meghatározását, amely a tervezett volumenek alapján kerül kialakításra, és fedezi a termelés fix költségét, valamint a profitot. A termékszintú kalkulációban ez az évente fizetendő fix díj szerinte nem kerül figyelembevételre.

d) Külsó piac nélkül a belsó eladó divízió értékesítésének jelentốs része a belsó értékesítés, és kapacitása minden szükséglet kielégítésére elegendó. Ez a szervezeti múködés a belsô szállító divízió szerepét kiszolgáló funkcióvá változtatja. Gyakorlatilag ellátja a belsô vevôrészleget az általa igényelt termékekkel. Ebben a helyzetben természetesen alapvetően a költségalapú, leginkább standard változó költségalapú ármeghatározás jellemző, de a termék jellegében, illetve a költségek feloszthatóságában felmerül néhány megválaszolandó kérdés. Ha a költségek a volumenváltozással nem szignifikánsan változnak, akkor az eladó időszakonként az árak változtatására kényszerül. Ha viszont a költségváltozás nem független a volumentől, akkor a transzferárak kialakítása az eladó költséginformációi és a vevô különféle szintú transzferárak alapján tervezett igénye szerint valósul meg. Elfogadott árak mellett az eladó felelőssége a rendszer múködtetése.

Ha a transzferár megállapítása a standard változó költségekre épül, akkor az eladórészleg fix költségeit az ár nem fedezi, azok az eredményét terhelik. Mivel azonban a részleg múködése a vállalat egészének érdeke, így természetesen a fix költségek vállalati általános szinten, illetve azon részlegek révén merülnek fel, amelyek az eladórészleg kiszolgálófunkcióját igénybe veszik. Ha egy részleggel áll kereskedelmi kapcsolatban az eladó divízió, akkor a fix költségek átterhelése előzetes megállapodás alapján egyszerúbb, ha viszont több részleg is vásárol az eladótól, akkor jellemzően az előzetes kapacitás-igénybevételi tervek alapján kerül az általános költség átterhelésre. Ez a módszer az eladó részérôl a kapacitáslehetôségek becslését jelenti, minél nagyobb kapacitáskihasználást, a vevôk részérôl pedig korrekt igénybevételi terveket, hiszen az alultervezett igénybevétel mellett kisebb fix költség átvállalásával a többi divízió eredményalakulását rontják, ami hosszú távon a belső konfliktusok miatt nem tartható.

A szervizrészleg tervezett fix költsége szétosztásának nagy előnye, hogy a terven felüli költségtételeket nem tudja a többi divízióra átterhelni, hogy megszünteti annak kockázatát, hogy a fix költség alakulása a volumentervekre hatással legyen, hogy a divíziók havi zárási folyamatait a költségkalkuláció időigénye nem befolyásolja. Mindemellett az eladó divízió fix költségei nemcsak a divízión belüli, hanem a többi divízió, így a vállalatvezetés kontrollja alatt is állnak.

e) Nincs külsó piaca a köztes terméknek, a belsó szállító jelentốs volument értékesít a belsó ügyletekben, kapacitása teljes kihasználásával sem tudja teljesíteni az igényeket. Ebben a helyzetben a d szituációhoz képest a vállalatvezetés interdivíziós kapcsolatokkal összefüggô feladatköre hangsúlyosabbá válik. Mivel a kapacitáskorlátok miatt a belsô igények kielégítése lehetetlen, a legjövedelmezóbb kapacitáskihasználást a vállalat érdekeinek figyelembevételével a vállalati szintú felelős döntési pozícióban lehet meghatározni. Ezáltal a transzferár az eladórészleg vonatkozásában elveszíti egyik jelentôségét, hiszen a tervezésben az elvárások csökkennek, a termékértékesítés elosztása felülrôl jövő döntéssé válik. Egyúttal egy hosszú távú probléma is előtérbe kerül, mégpedig, hogy milyen hosszan lehet a vállalaton belül az elégtelen kapacitás problémáját fenntartani.

Ez a feltételrendszer tehát a transzferár kialakítása szempontjából komoly belső folyamatszervezést igényel, az adminisztratív, vállalati szintű döntések hangsúlya nagy, az ármeghatározás maga programozott formában, optimalizálással történik.

Solomonshoz hasonlóan R. L. Benke és J. D. Edwards (1980) különféle szituációkat meghatározva, előnyben részesítették a vállalat profitmaximalizáló célját, háttérbe szorítva ezzel a teljesítménymérés jelentőségét. A belsô árak meghatározásakor nem preferálják a matematikai programozást, és az elméleti kutatások eredményei szerinti határköltség helyett a változó költséget ajánlják. Transzferárképletük a standard változó 
A transzferár meghatározása a felelősségi központok és a piaci viszonyok függvényében

\begin{tabular}{|c|c|c|}
\hline \multirow{4}{*}{ 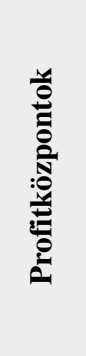 } & Szituációk & Transzferártechnikák \\
\hline & $\begin{array}{l}\text { 1. Tökéletes piac: minden vállalaton belül értékesített } \\
\text { termék a piacon is eladható. }\end{array}$ & $\begin{array}{l}\text { Uralkodó piaci ár (prevailing market price) = standard változó költség } \\
\text { + elvesztett haszon. }\end{array}$ \\
\hline & $\begin{array}{l}\text { 2. Kissé tökéletlen versenypiac esetén: minden belsó } \\
\text { értékesítésú terméknek van külsó piaca. }\end{array}$ & Beállított piaci ár (adjusted market price). \\
\hline & $\begin{array}{l}\text { 3. Tökéletes piac, vagy kissé tökéletlen piac: a legtöbb } \\
\text { értékesítés a piacon. A belső értékesítésben részt vevő } \\
\text { termékeknek nincs piaci áruk. }\end{array}$ & $\begin{array}{l}\text { Látszatár. Amíg a termék belső értékesítésre kerül, addig nincs piaci } \\
\text { ára, látszat piaci ára van, ami a standard változó költség és a nem külsó } \\
\text { értékesítésre termelt termékek elvesztett fedezeti összegeként értelmezhetô. }\end{array}$ \\
\hline \multirow{3}{*}{ 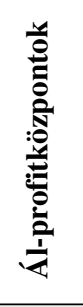 } & 1/a A legtöbb termék értékesítése vállalaton belül. & \multirow[b]{2}{*}{$\begin{array}{l}\text { Standard változó költség, mivel nincs a külsó értékesítésen elvesztett } \\
\text { haszon. A nyereségközpontok megvédik a fedezeti összeget } \\
\text { tartalmazó technikákat. }\end{array}$} \\
\hline & $\begin{array}{l}\text { 1/b A legtöbb termék értékesítése a piacon történik. } \\
\text { A belsó értékesítésú termékeknek nincs külsố piaca, az } \\
\text { előállításukhoz használt kapacitás nem használható a } \\
\text { külső értékesítésre szánt termékek elóállításához. }\end{array}$ & \\
\hline & 2. Szabad kapacitás. & $\begin{array}{l}\text { Standard változó költség, a kihasználatlan kapacitás elvesztett } \\
\text { fedezeti összege nulla. }\end{array}$ \\
\hline \multirow{2}{*}{ 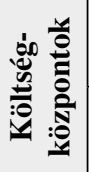 } & 1. Nincs külső ár a piaci viszonyok miatt. & $\begin{array}{l}\text { Standard változó költség, nincs elvesztett fedezet, fix költségek } \\
\text { idôszakos allokációja. }\end{array}$ \\
\hline & 2. Szabad kapacitás. & $\begin{array}{l}\text { Standard változó költség, nincs elvesztett fedezet, a kapacitáskihasználással } \\
\text { keletkezó pótlólagos fix költségek átterhelése a vevőrészlegre. }\end{array}$ \\
\hline
\end{tabular}

(Forrás: Ralph L. Benke Jr. - James Don Edwards (1980): Transferpricing :Techniques and Uses. p. 76 alapján)

költség és az elvesztett haszon alapján épül fel (lásd: 1. táblázat). A szituációk függvényében az általuk ajánlott ár lehet módosított ár, uralkodó piaci ár, látszatár vagy standard változó költség (Benke - Edwards, 1980).

A számviteli kutatások eredményeként a transzferárak kialakításának költségalapú, piaci alapú, sốt a vállalaton belüli sajátos elszámolási rendszer bevezetésével duális árazás mellett érvelók is megegyeztek abban, hogy valójában a belső árak meghatározása attól függ, hogy a menedzsment hosszú távú céljait mely módszerek segítik leginkább.

Anthony és Dearden ezt úgy fogalmazta meg, hogy a transzferárrendszer két fontos kritériuma (Anthony Dearden, 1980):

1. motiválnia kell a divízióvezetốket becsületes döntéshozásra, és ennek érdekében megbízható belsô kommunikáció kialakítására, azaz a divíziószintú döntéshozás nemcsak a divíziószintú profit emelkedésében, hanem a vállalati szintú nyereség növekedésében is látható,

2. nyomott árak, amelyek a külső szállítók által ideiglenesen kínált árak, általában elfogadhatatlanok transzferárként.

Általában véve szerintük a beszerzési ár és a transzferár politikája egymástól független döntési kör a vállalkozásnál. Kutatásaik során igyekeztek meghatározni azokat a körülményeket, amelyek az árképzés módsze- rének megválasztását leginkább alátámasztják. A piaci alapú árképzés mellett szavaztak abban a helyzetben, ha a köztes termék piaci ára értelmezhetô, és kényszeríti az eladórészleget make-or-buy (venni vagy eladni) döntésekre, mindamellett elégséges profitot tartalmaz. Ha mindkét részleg múködése autonóm, akkor a beszerzési és az árazási döntések egybeesnek. A vállalat maximális profitjának elérése érdekében azonban bizonyos korlátozások szükségesek, mint például azonos külső és belsô árak esetén a belsô beszerzések preferenciája, a külsô szállító idôlegesen nyomott árainak elutasítása, illetve a vállalatvezetés divíziókkal szembeni elvárásának figyelembevétele a beszerzési folyamatok kapcsán. Ezek természetesen sértik a kereskedelemmel foglalkozó divízió önállóságát.

Anthony és Dearden a költségalapú, standard teljesköltség és árréstartalmú ármeghatározást javasolják, ha a piaci árakról nincs elérhetô információ. Az árrés meghatározásánál a külső értékesítéseken általánosan elfogadott, vagy az adott piacon, iparágban jellemző, esetleg az eszközfelhasználások alapján beállított mértékú marginnal számolnak. Ôk is felismerték, hogy a végterméket értékesítő divízió számára az általa az optimális (maximális profitot biztosító) kibocsátás mellett realizált nyereség nem elegendô a vállalati profitcélok eléréséhez, így a transzferárrendszer ösztönzô funkciója nem érvényesül. Ennek a problémának 
a megoldására a fix költségek kapacitás-igénybevétel szerinti rendszeres szétosztását javasolták (ugyanúgy, mint Solomons vagy Benke), esetleg a teljes folyamaton realizált profit megosztását (eladási ár mínusz változó elóállítási és értékesítési költség). Azt is elfogadhatónak tartották, ha az értékesítórészleg a változó értékesítési költségekkel csökkentett külsô piaci áron értékesít, a vevôrészleg pedig a standard változó költségen. A különbség a konszolidálás révén látható a vállalati eredményben (Anthony - Dearden, 1980).

A számviteli kutatások terén nagy jelentôsége volt Robert S. Kaplan munkásságának. Legjelentôsebb eredménye a Balanced Scorecard modell, amely a vállalati stratégiai célok megvalósításának rövid távú tervezésében és értékelésében a gyakorlat által is igazolt eszköze (Kaplan - Atkinson, 1998). A transzferárkutatás terén megjelent munkáiban is felismerhető a menedzsmentszemlélet, magát a transzferárrendszert a gyakorlati alkalmazhatóság oldaláról közelíti és a vállalatvezetés eszközrendszerének részeként definiálja. Szerinte az elszámoló árak rendszerének a vállalati optimalizációs törekvéseknek, a nyereségmaximum szempontjából optimális tevékenységnek megfelelően kell kiépülnie, ugyanakkor a különbözó vezetői szintek teljesítményének tervezését, mérését és értékelését is kell, hogy szolgálja. Kaplan hangsúlyozta a részlegek közötti kereskedelmi ügyletek eredményhatásait, amelyek a divíziók profitcéljainak veszélyeztetésével a belső folyamatokra negatív hatással lehetnek. Nemcsak az fontos kérdés, hogy a beszerzési folyamatok vállalaton belüli múködtetése mennyiben összvállalati érdek, hanem hogy a divíziók profitcéljai elérése rövid távú döntésekkel, vagy a vállalati hosszú távú érdekek megvalósítása érdekében realizálódnak. Elemzéseiben a teljesítményértékelés hangsúlyozása mellett tehát a rövid és hosszú távú hatások is komoly figyelmet kaptak.

Kaplan szerint a mikroökonómiai elméletek szerinti határköltség a kapacitáskihasználás azon szintjén hozza összhangba a keresletet a kínálattal, ahol a kapacitásfüggő költségek termékszinten a legalacsonyabbak. Ennek a gyakorlati realitása nem igazolható. A teória alkalmazásakor a számviteli szakemberek alapvetően a rövid távú változó költségre épített, a kapacitás-igénybevétel fedezetére elegendő fedezettel kalkulált transzferárakat fogadják el. Kaplan a kapacitás fedezetére szolgáló költségtartalmat a haszonáldozat-költséggel helyettesíti, amely a termék belsố felhasználásával merül fel, és több nyereséget jelent, mintha a terméket a külsố piacon értékesítenék. Ez a rövid távú változó költségekre épített árazási módszer a szakemberek számára elfogadhatatlan, mivel alapvetően a rövid távú ármeghatározást szolgálja. Az árképzés azonban hosszú távú megfontolásra kell, hogy épüljön, hiszen a folyamatosan változó transzferárak megbízhatatlan és változó információt adnak a vállalkozás értékképzô folyamatairól, ezáltal gátolják a vállalatvezetést a folyamatok koordinációja és racionalizálása terén. A vállalati múködés hosszú távú tervezhetôsége a transzferárrendszer stabilitását igényli.

A felmérések szerint a leggyakrabban használt transzferár-kalkuláció a standard költségre épített teljesköltség-alapú árazás. A módszer hibája természetesen a hagyományos költségfelosztás sajátosságaiból adódik. A kapacitásköltségek termékekhez rendelése költségokozóktól függetlenül, önkényes alapon, leggyakrabban termelési volumen alapján valósul meg. Ez a kalkuláció magában hordozza azokat a már említett kritikus jellemzóket, mint a folyamatosan változó kapacitáskihasználás miatti volumenváltozást, ebból adódóan az elszámoló ár hosszú távon állandó és rövid távon változó részekból való tartalmát, így a költségmegtakarítások és kapacitáskihasználás megbízható elemzésének lehetőségét. A teljes költség meghatározása tipikusan nem az önköltségszámítás, hanem a teljes költség fedezete célra épül. Ha a köztes termék piacán az árinformációk elérhetók, akkor nincs realitása a teljesköltség-alapú kalkulációnak, viszont ha nincs piaca a köztes terméknek, akkor a teljesköltség-alapú ár a hosszú távú határköltség kategóriaként értelmezhetô megfelelően tervezett költségszerkezet esetén.

Kaplan megfelelő köztes megoldásnak látja a tevékenységalapú költségszámítás módszerét a transzferárak kialakításakor. A tevékenységalapú allokáció a kapacitásköltségek termékhez rendeléséhez költségokozók meghatározását, a költségek ezen keresztül való felosztását jelenti, a költségokozó igénybevételének alapján. A belső ügyletek árazásakor tehát a termékköltségen kívül a kapacitásfenntartó és termékfüggô általános költségek éves fix díjtétele kalkulálható. A múködésfenntartó költségekre kalkulált díj az árban a vevő divízió számára biztosítja a folyamatos szállítás lehetôségét az általuk készített tervek alapján. Ez megbízható tervezést igényel a vevơrészlegtốl, ezáltal rövid távon (éven belül) határköltség-alapú árképzést biztosít. Alultervezés esetén ugyan alacsonyabb beszerzési ár kerül megállapításra, de egyúttal a kockázata is fennáll a tevékenység problematikusságának az igények kielégítésének elégtelen szintje miatt. Az éves díj meghatározása természetesen attól is függ, hogy az eladó divízió profit- vagy költségközpontként múködik, azaz hogy van külső megrendelése, vagy kizárólag a belső ügyletek révén realizálódik a tevékenysége.

Kompetitív piaci feltételek között a piaci ár megfelelố alapot jelent a divíziók önállóságának és független- 
ségének érvényesítésére. Ha a hosszú távú piaci ár nem biztosít megfelelő profitot a vásárló divíziónak, akkor a vállalat dönthet a termék külsô piaci beszerzéséról, a gyártórészleg pedig a külsô piaci értékesítésról. Az persze egyértelmú, hogy a belső értékesítések általában mindkét divízió számára elônyt jelentenek a külső kereskedelmi ügyletekhez képest. Jelentős megtakarítások érhetốk el az értékesítési költségeken, a szállítási és szervizköltségeken, garanciaidôkön. Sok esetben a minőségi követelmények biztosítása, a termékkel kapcsolatos bizalmas információk is igénylik a belsố kereskedelmet. Ez esetben a piaci árhoz képest magasabb árak alkalmazása is előfordulhat. Ugyancsak figyelmet érdemel a külső árak alkalmazásakor a külső potenciális szállítók rövid vagy hosszú távú gondolkodása. A túlságosan alacsony árak jellemzóen nem tarthatók hosszú távon, csupán a piacszerzés érdekében kerülnek alkalmazásra a külsô szállítók által. Ezek a problémák jelzik a piac nem kompetitív jellegét, hiszen általában a kompetitív köztes termékpiac olyan feltétel a vizsgálódások során, mely a gyakorlatban nem jellemző. Ekkor viszont a belső folyamatok koordinációja a piaci árak révén meglehetôsen bonyolulttá válik, gyakorlatilag a piaci árak alapján való folyamat-összehangolás a vállalaton belül ellentétes a divíziók önállóságának elvével.

Összességében a kompetitív piac hiánya és a költségalapú árképzési lehetôségek korlátai miatt Kaplan a megegyezéses árképzést preferálta. Ha a piac nem monopolisztikus, az információáramlás megfelelő ahhoz, hogy a transzferár a haszonáldozat-költséggel közel azonos legyen, a vállalaton belüli üzleti aktivitás lehetósége fennáll, a piaci folyamatok ismerete alapján megbízható ajánlatok kerülnek elfogadásra a külsố kapcsolatokból, valamint a felsố vezetés támogató részvétele mellett a megegyezéses árképzésnek számos elónye lehet. Ugyanakkor az alkalmazás korlátjaként értékelhető Kaplan szerint (Kaplan - Atkinson, 1998: 461. old.):

- a folyamatba bevont vezetók idővesztesége,

- a tárgyalások során a divíziók közötti érdekütközések miatti konfliktusok felerősödése,

- a vezetók megegyezó képessége, azaz szubjektív elemek komoly befolyással vannak a végeredményre,

- a felső vezetés folyamatértékelő tevékenységének és a vitás kérdések rendezésének időigénye,
- esély van a haszonáldozat-költséget fedezó ár melletti kibocsátási szintnek az optimálisnál alacsonyabb meghatározására.

Kaplan ezeket a hátrányokat felismerte, de sokkal részletesebben nem foglalkozott a kérdéssel. Összességében az említett hátrányok jól mutatják a megegyezéses transzferárrendszernek a szubjektív voltát, a vezetối képességek jelentôségét.

Robert G. Eccles (1985) szerint a transzferár-politika egyike azon vállalatvezetési eszközöknek, melynek kialakítása, implementálása és folyamatos alkalmazása számtalan elónnyel jár, ugyanakkor folyamatos figyelmet igényel, hiszen számtalan belsố konfliktus forrása lehet. Bevezetéséhez a jogosultságok és felelósségi körök hatékony múködésének vizsgálata szükséges. Ennek jellemzésére Eccles két kategóriát emel ki: az egyik a vállalati teljesítmény, a másik az egyéni korrektség. Az általa feltett fô kérdés, hogy van-e megfelelő szintú felelőssége és elegendő jogosultsága az eróforrások felett a vezetóknek ahhoz, hogy a tevékenységükkel korrekt módon hozzájáruljanak a vállalati teljesítményhez. Ez a kérdés a rendszer kritikus pontjára tapint rá, miszerint csak olyan eredményekért tehetốk felelőssé a vállalati hierarchiában a vezetók, amelyek eléréséhez szükséges erőforrások felett rendelkezési joguk van. Egyúttal az is egyértelmúsíthetô, hogy a vezetôi szintek korrekt múködése csak akkor biztosítható, ha a felelősségi pozícióban lévő vezetôk munkájuk értékelését és jutalmazását korrektnek érzik. Az egyéni korrektség tehát az egyén oldaláról hozott felelős döntések fogalma mögött az egyén elégedettségét is jelzi a vele szemben kialakított elvárásokban és értékelésekben. (lásd 1. ábra)

1. ábra

\section{A transzferárazás okai és hatásai}

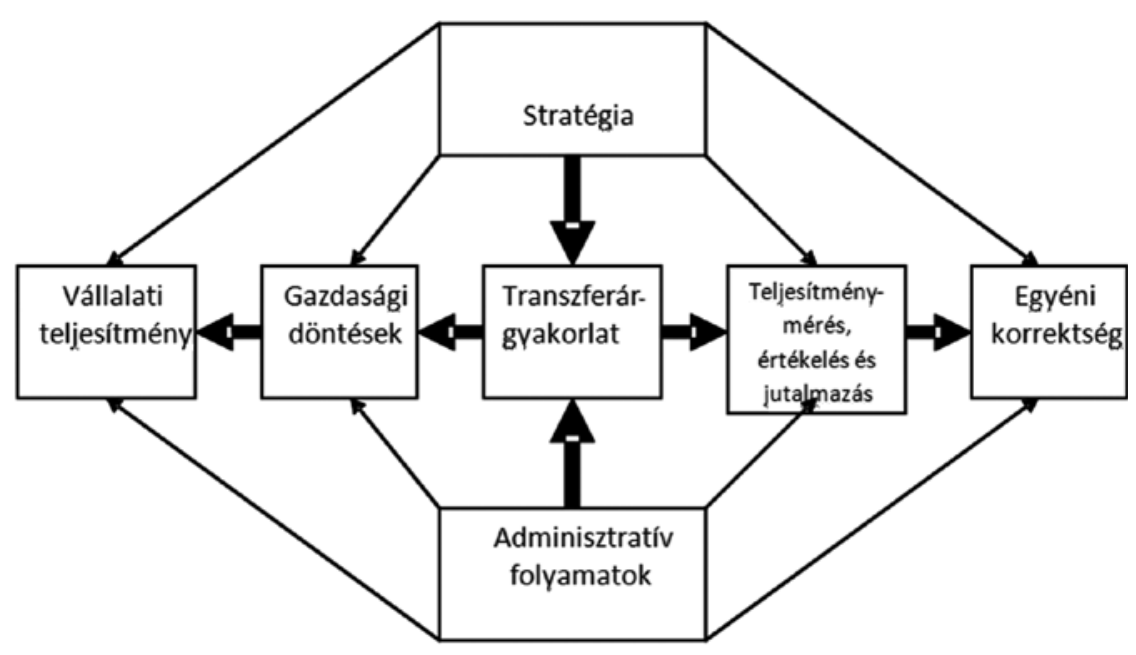

(Forrás: Eccles:The Transfer Pricing Problem: p. 7.) 
A jogosultság és felelôsség kérdésköre a transzferár-politika vonatkozásában különösen fontos terület. A transzferár szerepe szerint az egyik részleg számára bevételoldalról, a másik részleg számára költség/ráfordítás oldalról érinti az eredményt. Maga a transzferárrendszer persze a vállalati stratégiai célok érdekében kialakított árazási mechanizmus, azaz a múködtetése a vállalati tevékenységben szükségszerú és elvárt, így szoros kötődése van a teljesítményértékeléshez is. A vállalatvezetés számára tehát hangsúlyos terület a transzferárrendszer kialakítása során a teljesítményértékelésre gyakorolt konkrét hatások vizsgálata, illetve a bevezetés során a belsố kommunikáció révén a felelősségi körökkel kapcsolatos elvárások tisztázása. Ellenkező esetben a kialakuló belsố feszültség, az egyéni érdekek és a vállalati érdekek diszharmóniája a telje- a hagyományos típusú integráció, mely kimondottan a gyártórészleg által előállított köztes termék kereskedelmére alakítja ki a belsố vevő feladatkörét. Ettôl szélesebb kapcsolatrendszerre építve említhetố az az integrációtípus, mely kilép a „csak” termékkereskedelem kötelékébő́l és az együttmúködés egyéb előnyeit (technikai, technológiai, fejlesztési stb.) is erósíti a szervezeti rendszeren belül. Ugyanakkor vannak olyan vállalatok, amelyek esetében a divíziók tevékenységének sajátosságai nem igénylik, esetleg nem engedik meg az együttmúködést, kapcsolatuk esetleges, vagyis a vertikális integráció nem a vállalati stratégia jellemzóje. Természetesen ezek egyéb kombinációi is elképzelhetốk. A vertikális integráció és a kialakítható transzferár-politika összefüggéseit szemlélteti a 2. táblázat.

2. táblázat

A stratégia és a transzferár-politika összefüggései

\begin{tabular}{|c|c|}
\hline Stratégia a részlegek integrációjára & Transzferár-politika \\
\hline Hagyományos vertikális integráció az alacsony beszerzési költség érdekében & Rögzített belső kereskedelem - költségalapú árképzés \\
\hline Vertikális integráció hagyományostól eltéró formái & Rögzített belső kereskedelem - piaciár-alapú árképzés \\
\hline Vertikális integráció hiánya & Autonóm kereskedelem \\
\hline Az említett típusok kombinációja & Kettős árazás \\
\hline
\end{tabular}

(Eccles: The Transfer Pricing Problem alapján)

sítménymutatókban rövid távú eredmények elérésére ösztönöznek.

Külön figyelmet érdemelnek a teljesítménymutatók maguk. A legjellemzóbb mérók többnyire az eredmény különböző szintjein mért értékek. Ott persze, ahol az eredmény valamilyen belsố mechanizmus révén befolyásolt érték, a teljesítmény nem feltétlenül az eredménykategóriákra kell, hogy épüljön. Ennek megfelelôen a különbözố vezetôi szinteken a teljesítmény fogalmának tisztázása vezet a motiváló és ösztönző értékelőrendszer kialakításához. Ebból adódóan a pénzügyi mutatók mellett a teljesítmény nem pénzügyi típusú mérési lehetőségei egyértelmúbb elvárási rendszerek kiépítésével, a transzferárak teljesítménymérésre gyakorolt hatásának csökkentésével az egyéni elégedettség és elhivatottság irányába hatnak.

Ugyanakkor a transzferárrendszer a részlegek közötti kereskedelmi ügyletekhez kötődő kategóriaként igényli a szervezeti rendszeren belül a divíziók együttmúködésének vizsgálatát, természetesen a vállalati stratégia függvényében. Eccles alapvetóen négy alaptípust vázol fel a belsó folyamatok összehangolására a vállalati tevékenység sajátosságaihoz szorosan kötve (Eccles, 1985). Szerinte a vertikális integráció két alapvetô formáját lehet megkülönböztetni. Az egyik
Összességében tehát a transzferár-politika legfóbb jellemzőiként értékelhetô, hogy a vállalati stratégia alapján kerül kialakításra, befolyásolja a vezetói szinteken kialakított jogosultsági és felelôsségi köröket, ezért hatása van a gazdasági döntésekre és a teljesítménymérés kapcsán az igazságosság mértékének megítélésére.

\section{Szervezeti modellek és transzferárazás}

Swieringa és Waterhouse tanulmánya szerint a transzferárrendszerek meghatározásakor alapvető érdek a vállalati célokra épített, a viselkedési és cselekvési következetességet a teljesítménymérés rendszerén keresztül érvényesító, a döntéshozás során a gazdasági racionalitást előtérbe helyező árrendszer kialakítása (Swieringa - Waterhouse, 1982). Modellalkotásuk során a hagyományos, racionális alapon kialakított, a vállalat hosszú távú érdekeinek elérését célzó transzferárrendszer mellett, négy modell keretei között vizsgálták a transzferár-meghatározást. Az egyik a viselkedési modell, amelyben a szervezeten belüli érdekegyeztetési folyamatok alakítják a belsô árakat. A másik a szeméttartó modell, amelyben a vállalat nem előzetes célokra építi a rendszert, hanem a folyamatokat követve, az adott helyzetben elóállt választási lehetőségek alakítják azt. A harmadik a szer-

\section{VEZETÉSTUDOMÁNY}


vezó modell, amelyben a múlt tapasztalataira építve történik a támogatott céloknak megfelelő transzferár kialakítása. A változtatás ugyanakkor a rendszerben elfogadott. Végül a piacok és hierarchiák modell keretein belül a gazdaságosság érdekében, a szabályozottság révén, a környezeti bizonytalanság megszüntetése a cél.

Swieringa és Waterhouse kutatási eredményei felhívták a figyelmet a transzferárrendszerekkel kapcsolatos külsố környezeti és belsố szervezeti tényezók, jellemzók hatásaira, melyek a biztosított információk, folyamatok és érdekek alapján meghatározzák magát az árképzési mechanizmust. A témával kapcsolatos kutatások közül Schweikart, valamint Birnberg és Shields munkássága alapján S. Borkowski a 2 . ábrának megfelelően összegezte a transzferármódszer választását befolyásoló tényezóket, és készítette el ennek bázisán a transzferártechnikák alkalmazására vonatkozó folyamatábrázolást (Borkowski, 1990). Jól látható, hogy a külsô környezeti tényezốk (mint például a köztes termék piaci ára, a vállalat gazdasági stabilitása, gazdasági előnyei stb.) hatással vannak a belsố szervezeti jellemzók alakulására. A vállalat belsố felté-

\section{Transzferárválasztás a vállalaton belül}

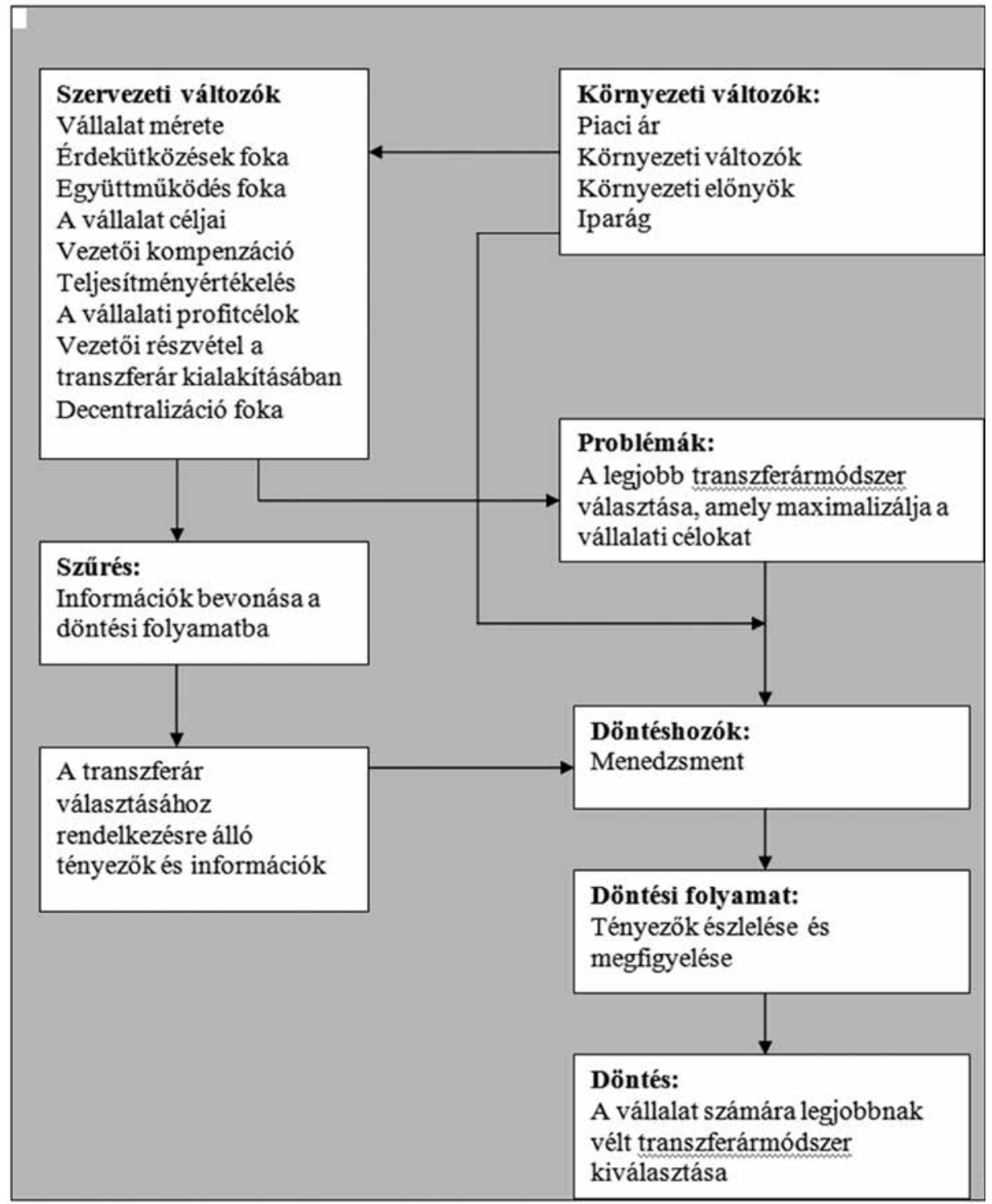

(Borkowski, S.C. (1990):

Environmental and Organizational Factors Affecting Transfer Pricing: A Survey. Journal of Management Accounting Research, Fall: p. 83.) telrendszere jó alapot képez az ármeghatározáshoz szükséges információk előkészítése terén, de az elszámoló árak megválasztásakor a vállalati célok megvalósítása ugyancsak hangsúlyos.

\section{Nemzetközi transzferárazás}

Kétségtelen, hogy az elmúlt kb. harminc évben a tudományos és technikai előrelépések, amelyek következtében a közlekedés, az infrastruktúra, az adatátvitel és a kommunikáció ugrásszerú fejlődési folyamaton ment keresztül, lényegesen megkönnyítette a vállalkozások nemzetközi kapcsolatainak kialakítását, gaz-

dasági tevékenységük kiszélesítését. A nemzetközi gazdasági kapcsolatok jelentősége, illetve az ezekkel együtt járó kockázatok növekedése a nemzetközi szervezeteket átfogó és általános jellegú iránymutatási, szabályozási környezet kialakítására ösztönzi. A gazdasági folyamatok átláthatóbb, standardizáltabb, és ezáltal a kockázatok tekintetében is biztonságosabb együttmúködési kereteinek kialakítása az alapvetố cél. E tekintetben a transzferárak kategóriája, illetve az a gazdasági kapcsolatrendszer, amely multinacionális vállalati vonatkozásban értendő, különös figyelmet kapott az elmúlt húsz évben. A multinacionális vállalat transzfer- 
ár-politikája ugyanis, a vállalatvezetési eszköz kategórián túl, nemcsak a vállalati stratégiai célok és a leányvállalatok gazdasági tevékenységének összehangolását, a teljesítménymérés rendszerének kiépítésével a motivációs és ösztönzőrendszer fenntartását szolgálja, hanem a nemzetközi versenyben való pozíció erősítését és a lehetôségek kihasználását, a gazdasági környezeti különbségekben rejló elônyök érvényesítését is, leginkább az adózási és devizakockázati lehetőségekben.

Abdallah (2004) a multinacionális vállalatok hatékony transzferárrendszerének kritériumait a következókben foglalja össze (Abdallah, 2004: p. 27.):

A nemzetközi transzferárrendszer részeinek összefüggése

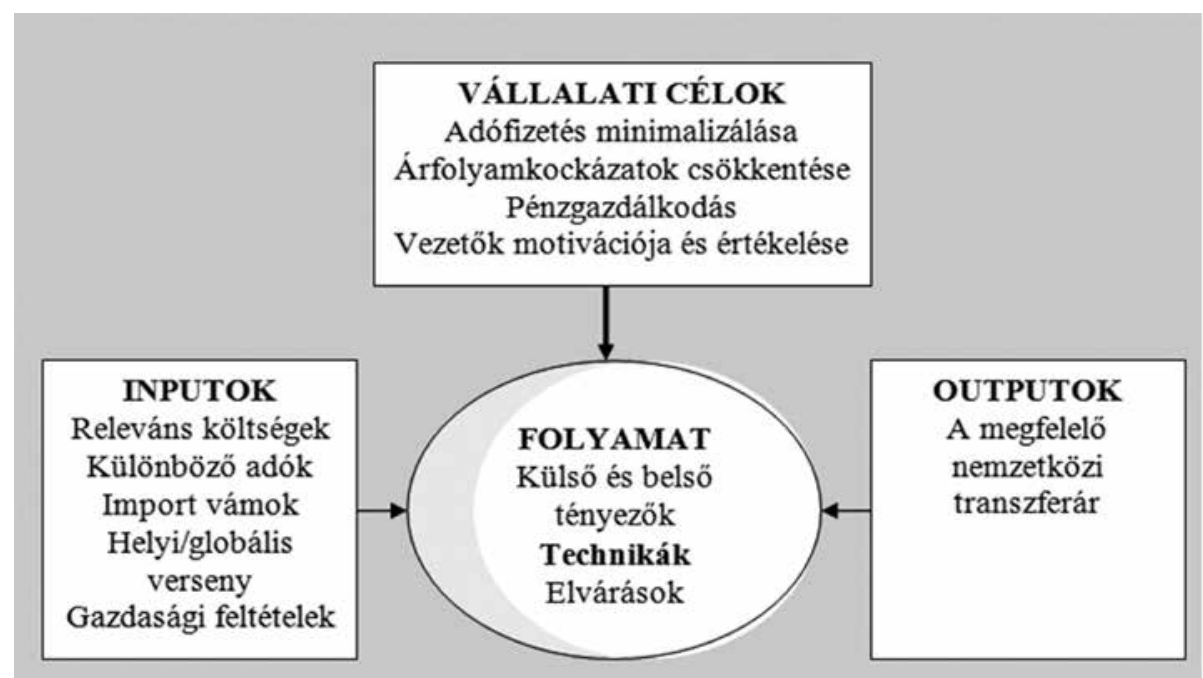

(Forrás: Abdallah (2004): Critical Concerns in Transfer Pricing and Practice: p. 29.)

A nemzetközi transzferár-politika

1. megfelelő eredményméróket alakít ki a külföldi leányvállalatok teljesítményének értékelésére, amellyel a csoportszintú profithoz való hozzájárulásuk mérhetó,

2. megfelelő információt szolgáltat a vállalatvezetésnek a gazdasági döntésekhez,

3. múködtetése a multinacionális vállalat összteljesítményét növeli,

4. motiválja a leányvállalatok vezetőit hatékonyságuk és üzleti területük eredményének maximalizálására a vállalati céloknak megfelelôen,

5. minimalizálja a multinacionális vállalat nemzetközi tranzakciós költségeit a vámokban és adókban, a devizakockázatokban, pénzügyi manipulációk miatti veszteségekben és a külföldi állami szabályozókban.

A jól kialakított és múködő transzferárrendszer a multinacionális vállalat számára a vállalati és a leányvállalati célok jobb összehangolását, célirányosabb teljesítménymérést, kisebb adó- és vámkötelezettségeket, motiváltabb vezetőket, kisebb devizakockázatot, és mindezek révén jobb versenypozíciót jelent a nemzetközi piacon. Abdallah szerint (2004) a nemzetközi transzferárrendszer kialakításakor négy fontos jellemzôt kell figyelembe venni. Alapvetően a vállalati célokat, az árpolitika kialakításához szükséges információkat, a transzferárrendszer múködési feltételeit, illetve a kialakított transzferárrendszert magát, ahogy ezt a 3. ábra szemlélteti.

\section{Összefoglalás}

A hazai szakmai publikációk jellemzően a transzferárazást adózási vonatkozásban tárgyalják. A kérdéskör e vetülete természetesen alapvetó a vállalkozások számára az adókockázatok minimalizálása érdekében. A transzferárrendszer maga azonban a vállalati folyamatok függvényében a vállalatvezetés eszközrendszerének része, a stratégiai célokat alapvetôen szolgáló tényezô. Kialakítása során figyelembe kell hogy vegyék a csoportszintű eredményérdekeket, a rendszer átláthatóságával a minél hatékonyabb alkalmazhatóság kritériumát, valamint a stabilitás követelményét (Mangol, 2009). Implementálása a vállalati szervezeti és üzleti sajátosságok révén lehetséges, de hatékony múködtetése folyamatos követést és hatásvizsgálatot kíván. Az árazás nem egzakt kategóriajellege miatt a belsố elszámoló árak kialakításánál sem képzelhetố el egyértelmú szabályrendszer, nem létezik általános érvényư eljárás. E vonatkozásban a nemzetközi menedzsmentkutatások jelentős eredményeket értek el a kategória helyének vizsgálata során. Vannak, akik a közgazdasági modellek bázisán, vannak, akik a számviteli kategóriák és összefüggések, illetve olyanok is, akik a szervezeti rendszerek múködési folyamatainak vizsgálata révén foglaltak állást. Mindannyian egyetértettek azonban az árazás, és így a belső ügyletek árazásának komplexitásában, a feltételrendszer összetettségében.

Célom az volt, hogy a sokszor oly negatívan kezelt transzferárprobléma vállalatvezetési eszközjellegét hangsúlyozzam. Ennek első lépése természetesen a vonatkozó szakirodalom áttekintése, melybôl most ízelítôt 
adtam. Kutatómunkámat empirikus vizsgálattal folytatom, melynek célja a transzferárrendszer és a dokumentáció megítélése a vállalatvezetés szemszögéból. Arra keresem a választ gyakorló szakemberek megkérdezésével, hogy a belső árazás szisztematikus múködésének és a teljesítményértékeléssel való kapcsolatának van-e egyértelmú helye a vállalati menedzsment asztalán?

\section{Lábjegyzet}

Jack Hirshleifer (1925-2005) elméleti közgazdász, akinek munkássága kiemelkedő jelentőségú a decentralizált szervezeti formában múködô vállalkozások transzferárképzési lehetôségeinek kutatásában.

\section{Felhasznált irodalom}

Adams L. - Drtina R. (2010): Multinational Transfer Pricing: Management Accounting Theory versus Practice. Management Accounting Quarterly, Spring, vol. 11

Anthony, R.N. - Dearden J. (1980): Management Control Systems. 4th ed. Homewood: Prentice Hall

Anthony, R.N. - Govindarajan, V. (2009): Menedzsment kontroll-rendszerek. Budapest: IFUA Horváth \&Partners

Barakonyi K. (2002): Stratégiaalkotás II. Stratégiai menedzsment. Budapest: Nemzeti Tankönyvkiadó

Benke, R.L. - Edward, J.D. (1980): Transfer Pricing: Techniques and Uses. New York: National Association of Accountants

Borkowski, S. C. (1990): Environmental and Organizational Factors Affecting Transfer Pricing: A Survey. Journal of Management Accountin Research, Fall: p. 78-99.

Bosnyák J. - Gyenge M. - Pavlik L. - Székács P.-né (2010): Vezetôi számvitel. Budapest: Saldo

Cook, P.W. Jr. (1955): Decentralization and the TransferPrice Problem. The Journal of Business (Chicago Journals), Vol. 28, No. 2: p. 87-94.

Cox, J.F. - Howe, W.G. -Boyd, L.H.(1997): Transfer Pricing Effects on Locally Measured Organization. Industrial Management, May/April: p. 20-29.

Dean, J. (2009): Decentralization and Intracompany Pricing. Harvard Business Review, May: p. 65-74.

Drury, C. (2008): Management and Cost Accounting. 7th edition, London: South-Western Cengage Learning EMEA

Dürr, O.M. - Göx, R.F. (2011): Strategic Incentives for Keeping One Set of Books in International Transfer
Pricing. Journal of Economics and Management Strategy, Spring: p. 269-298.

Eccles, R.G. (1985): A Theory for Practice. London: Lexington Books

Eccles, R.G. (1983): Control with fairness in transfer pricing. Harvard Business Review, November/December: p. 149-161.

GaálZ. - Szabó L. (2007): A menedzsment alapjai. Veszprém: Pannon Egyetemi Kiadó

Hirshleifer, J. (1956): On the Economics of Transfer Pricing. Chicago Journals, The Journal of Business, Vol. 29, No 3. July: p. 172-184.

Hirshleifer, J. - Glazer, A. - Hirshleifer, D. (2009): Mikroökonómia, árelmélet és alkalmazásai - Döntések, piacok és információ. Budapest: Osiris

Horgren, C.T. - Datar, S.M.- Rajan, M.V. (2012): Cost Accounting. Harlow: Pearson Education Limited

Johnson, H.T. (1975): The Role of Accounting History in the Study of Modern Business Enterprise. The Accounting Review, July: p. 444-450.

Kaplan, R.S. - Atkinson, A.A. (1998): Advanced Management Accounting. Upper Saddle River, N. J.: Prentice Hall

Lynch, R.M. - Williamson, R.W. (1983): Accounting for Management Planning and Control. London: McGrawHill

Mangol Cs. (2009): A transzferárazás mint irányítási eszköz. Vezetéstudomány, XI. évf. 12. szám

McWatters, C.S. - Zimmerman, J.L. - Morse, D.C. (2008): Management Accounting Analysis and Interpretation. Upper Saddle River, N. J.: Prentice Hall

Ronen, J. - McKinney, G. (1970): Transfer Pricing for Divisional Autonomy. Journal of Accounting Research, Spring: p. 99-112.

Sharav, I. (1974): Transfer Pricing - diversity of goals and practices. The Journal of Accountancy, April: p. 56-62.

Solomons, D. (1985): Divisional performance: measurement and control. Princeton, N. J.: Markus Wiener Publishing

Szabóné V.T. (2011): Az árazás számviteli vonatkozásai. Számvitel - Adó - Könyvvizsgálat, LIII. évfolyam, 2. sz.: p. 80-82.

Swieringa, R.J. - Waterhouse, J.H. (1982): Organizational Views of Transfer Pricing. Accounting Organizations and Society, Vol. 7, No. 2: p. 149-165.

Watson, D.J.H. - Baumler, J.V. (1968): Transfer Pricing: A Behavioral Context. The Accounting Review, July: p. 466-474. 